\title{
BONE MARROW NECROSIS: A RARE COMPLICATION OF HERBAL TREATMENT WITH HYPERICUM PERFORATUM (ST. JOHN'S WORT)
}

\author{
Yusuf Ziya Demiroglu', Tuba Turunc Yeter ${ }^{1}$, Can Boga' ${ }^{2}$,Hakan Ozdogu ${ }^{2}$, Ebru Kizilkilic ${ }^{2}$, Nebil Bal ${ }^{3}$, Ilhan Tuncer ${ }^{3}$, \\ Hande Arslan ${ }^{4}$
}

University of Baskent, School of Medicine, Adana Teaching and Medical Research Center, Adana, Turkey: Department of Infectious Diseases and Clinical Microbiology ${ }^{1}$, Department of Hematology ${ }^{2}$, Department of Pathology ${ }^{3}$; University of Baskent, School of Medicine, Ankara, Turkey: Department of Infectious Diseases and Clinical Microbiology ${ }^{4}$

\begin{abstract}
Summary: A 22-year-old man presented with fever and ulceration of the oral mucosa. The patient had pharyngeal and esophageal candidiasis. For the 3 weeks prior to presentation, he had been taking approximately $1000 \mathrm{mg} / \mathrm{day}$ of flowering herbs (Hypericum perforatum $L$, known as St. John's wort) for treatment of depression. A complete blood count on the first day of hospitalization showed agranulocytosis and normocytic anemia. His condition worsened, and he developed progressive dysphagia. A bone marrow biopsy on day 3 revealed bone marrow necrosis. After the diagnosis was established (day 3 of hospitalization), treatment with granulocyte colony-stimulating factor $48 \mathrm{U} /$ day, intravenous immunoglobulin $400 \mathrm{mg} / \mathrm{kg}$, and amphotericin B $100 \mathrm{mg} / \mathrm{day}$ was initiated. The patient did not respond, and died within one week of the diagnosis. This cases suggests that Hypericum species may lead to severe hematologic toxicity, with conditions involving bone marrow necrosis.
\end{abstract}

Key words: Bone marrow necrosis; Hypericum perforatum L; St John's wort; Agranulocytosis; Myelotoxicity

\section{Introduction}

Hypericum perforatum $L$ (St John's wort) is a member of the Hypericum genus, which includes some of the most widely used herbal substances $(8,19)$. This plant possesses antimicrobial properties and is used to treat depression; however, it has been implicated in drug interactions $(4,12,16)$. Herbal remedies can alter a patient's hematological status and cause abnormal blood cell count results (1), but the impact of St. John's wort on bone marrow is unknown. In this case report, we describe a patient who developed fatal bone marrow necrosis associated with use of St. John's wort.

\section{Case Report}

A 22-year-old male was admitted to our hospital with fever, oral ulceration and fatigue. He had been well until 7 days earlier, when he developed a sore throat and a fever of $39.2{ }^{\circ} \mathrm{C}$. That evening, he visited the Ear, Nose and Throat Department of another hospital. The only abnormalities detected on physical examination were temperature $40.2{ }^{\circ} \mathrm{C}$ and pharyngeal hyperemia. A chest radiograph was unremarkable. Laboratory investigations revealed normal serum levels of blood urea nitrogen, creatinine, gluco- se, and normal urine analysis. No hematologic testing was done. A throat swab was taken, and the culture grew normal flora. Although the patient was diagnosed with a viral syndrome was initiated empirical amoxicillin therapy. However, when his fever persisted he came to our hospital.

On admission to our center, a complete history is taken before a physical exam. He had no history of travel to rural/agricultural areas, nor any exposure to animals. He did not use alcohol, tobacco or illicit drugs. There was a history of depression, and the patient had been taking fluoxetine (Prozac ${ }^{\circledR}$, Lilly) $90 \mathrm{mg} /$ day for 3 months. For the 3 weeks prior to admission, he had also been taking roughly 1000 $\mathrm{mg}$ /day of flowering herbs of St. John's wort. His vital signs were temperature $38.2{ }^{\circ} \mathrm{C}$, pulse 120 beats/min, respirations $20 / \mathrm{min}$, and blood pressure $100 / 50 \mathrm{mmHg}$. Physical examination of the oropharynx revealed ulceration of the buccal mucosa, postnasal exudates, and pharyngeal thrush involving the tonsils and uvula. No lymphadenopathy or organomegaly was detected. A single maculopapular eruption was detected on the right side of the abdomen. Results of hematologic and immunologic testing done on the first and third day of hospitalization are shown in Tab. 1. The peripheral blood smear on the day of admission showed normocytic anemia and agranulocytosis. 
Tab. 1: Hematologic and immunologic data for the case.

\begin{tabular}{|l|c|c|c|}
\hline & Day of Admission & Day Three & Normal Range \\
\hline Hematocrite & 31 & 18 & $40-53$ \\
\hline MCV $(\mathrm{fl})$ & 81 & 80 & $12-16$ \\
\hline $\mathrm{Hb}(\mathrm{g} / \mathrm{dl})$ & 10 & 6 & $4.5-5.9$ \\
\hline $\mathrm{RBC}\left(\mathrm{M} / \mathrm{mm}^{3}\right)$ & 3.6 & 0.23 & $4.50-11.0$ \\
\hline $\mathrm{WBC}\left(\mathrm{M} / \mathrm{mm}^{3}\right)$ & 0.64 & 83.000 & $130.000-400.000$ \\
\hline PLT $\left(\mathrm{K} / \mathrm{mm}^{3}\right)$ & 464.000 & & $40-72$ \\
\hline Differantial count $(\%)$ & & 1.95 & $20-47$ \\
\hline Neutrophils & 1.92 & 76.2 & $3-8$ \\
\hline Lymphocytes & 75.8 & 22.2 & $0-8$ \\
\hline Monocytes & 20.7 & 1.26 & $26-36$ \\
\hline Eosinophils & 0.17 & 4.30 & $11-14$ \\
\hline Fibrinogen $(\mathrm{g} / \mathrm{L})$ & 4.30 & 30.7 & $0.85-1.15$ \\
\hline Partial thromboplastin time $(\mathrm{s})$ & 56.2 & 15.2 & $0-10$ \\
\hline Prothrombin time & 19.60 & 1.40 & $0-20$ \\
\hline INR & 1.9 & & $0-62$ \\
\hline D-dimer $(\mu \mathrm{g} / \mathrm{ml})$ & 0.72 & 36 & $0-9.10$ \\
\hline ESR $(\mathrm{mm} / \mathrm{h})$ & 47 & & $0-5$ \\
\hline Antinuclear antibodies & negative & & \\
\hline c-ANCA & negative & & $0-8.10$ \\
\hline IL-1b $(\mathrm{pg} / \mathrm{ml})$ & 5.00 & & \\
\hline IL-2R $(\mathrm{U} / \mathrm{ml})$ & 7310 & & \\
\hline TNF-alpha $(\mathrm{pg} / \mathrm{ml})$ & 15.8 & & \\
\hline IL-6 $(\mathrm{pg} / \mathrm{ml})$ & 266.00 & & \\
\hline IL-8 $(\mathrm{pg} / \mathrm{ml})$ & 3467 & & \\
\hline IL-10 $(\mathrm{pg} / \mathrm{ml})$ & 18.70 & & \\
\hline
\end{tabular}

INR: International normalization ratio; IL: Interleukin; TNF: Tumor necrosis factor; CRP: C-reactive protein, ANCA: Antineutrophil cytoplasmic antibodies.

Serum biochemistry analysis on admission revealed total bilirubin $4.9 \mathrm{mg} / \mathrm{dL}$, direct bilirubin $3.4 \mathrm{mg} / \mathrm{dL}$, serum albumin $3.1 \mathrm{~g} / \mathrm{dL}$, blood urea nitrogen $22 \mathrm{mg} / \mathrm{dL}$, creatinine $1.0 \mathrm{mg} / \mathrm{dL}$, lactate dehydrogenase $202 \mathrm{IU} / \mathrm{L}$, alanine aminotransferase $404 \mathrm{IU} / \mathrm{L}$, and aspartate aminotransferase 97 IU/L. By the third day of hospitalization, the levels of these two liver enzymes had dropped to $68 \mathrm{IU} / \mathrm{L}$ and $30 \mathrm{IU} / \mathrm{L}$, respectively. Cytokine levels (IL-1b, IL-2R, IL-6, IL-8, IL10, TNF-alpha) in plasma were analyzed by using chemiluminescent method and immulite hormon autoanalyser (Diagnostic Product Corporation, IL, USA). All cytokine levels in plasma except IL-1b were found to be higher than normal range (Tab. 1). Serologic testing was also done on the first day of hospitalization. The results for hepatitis $\mathrm{B}$ and $\mathrm{C}$ viruses, human immunodeficiency viruses (HIV) -1 and -2 , parvovirus B19, Epstein-Barr virus (EBV) immunoglobulin (Ig) M, herpes simplex viruses 1 and 2, cytomegalovirus IgG and IgM, rubella, Brucella spp., typhoid fever, syphilis, and Toxoplasma IgM were all negative.

On the second day of hospitalization, chest radiography and abdominal computed tomography showed nothing remarkable. Computed tomography of the paranasal sinuses revealed sinusitis on the right side. Electrocardiography showed sinus tachycardia (rate 120 beats/min). Abdominal ultrasound was normal. Multiple blood, bone marrow and urine cultures were also done on day 2 , and none of these showed growth. A culture of material from the oropharynx grew mixed flora, and the majority of the isolates were Klebsiella spp. and Enterobacter spp. The hemoglobin level decreased from 10 to $6 \mathrm{~g} / \mathrm{dL}$ within 3 days, and schistocytes were seen in peripheral blood smear on day 3 , which reflects microangiopathic hemolytic anemia.

Based on the abnormal findings on the complete blood cell count and the peripheral smear, the bone marrow of the posterior iliac crest was aspirated and biopsied on the third day of hospitalization. The aspirate showed marrow necrosis, with only a few mononuclear cells and histiocytes preserved. Detailed histopathologic examination of the bone marrow revealed marked decreased numbers of hemapoietic cell series, which are megakaryocytic, erythroid and myeloid series, and cellularity was $15 \%$. Focal bone marrow necrosis was estabilished with necrotic cells and fat necrosis. There were no phagocytic activity and necrotic cell debris around the necrotic focus. With these findings the 
diagnosis was hypocellular bone marrow with focal necrosis (Figure 1).

The patient received meropenem $\left(\right.$ Meronem $^{\circledR}$, AstraZeneca) $6 \mathrm{~g} /$ day and amikacin (Mikasin ${ }^{\circledR}$, Abfar) $1 \mathrm{~g} /$ day before and after the diagnosis was established. Repeat blood testing on the second and third days of treatment showed that the neutropenia was becoming more severe. The patient developed progressive dysphagia. Endoscopic examination of the esophagus showed candidal esophagitis. To manage the bone marrow necrosis and associated clinical signs, we initiated treatment with granulocyte colony-stimulating factor (filgrastim, Neupogen ${ }^{\circledR}$, Roche) $48 \mathrm{U} /$ day, a $400 \mathrm{mg} / \mathrm{kg}$ bolus of intravenous I g (Endobulin $\mathrm{S} / \mathrm{D}^{\circledR}$, Baxter) to suppress cytokines, and amphotericin B (Fungizone ${ }^{\circledR}$, BristolMyers Squibb) $100 \mathrm{mg} /$ day. However, there was no response to treatment, and the patient died of cardiac arrest on the eighth day of hospitalization.

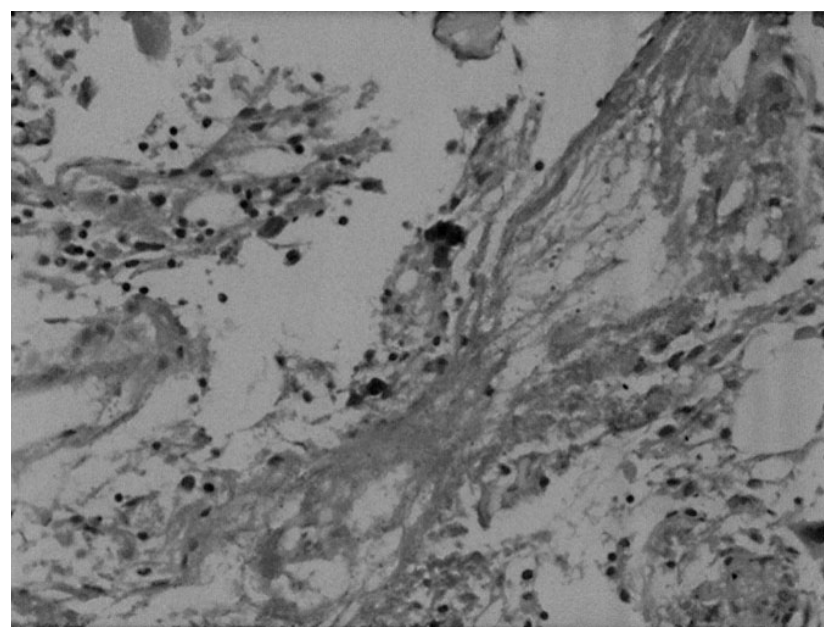

Fig. 1: Focal bone marrow necrosis (arrow)(H\&E x100).

\section{Discussion}

The most prominent finding in this case was bone marrow necrosis. It has been reported that beside agranulocytosis, anemia and thrombocytopenia can be observed $(90 \%$ and $80 \%$ respectively) in patients with bone marrow necrosis (11). In our case with agranulocytosis, thrombocytopenia developed following microangiopathic hemolytic anemia, which often occures in the case of bone marrow necrosis $(7,10)$. Necrosis of normal hematopoietic elements with gelatinous transformation has been described in patients with hematooncological disease, adenocarcinoma, typhoid fever, systemic lupus erythematosus and tuberculosis $(7,9,14,15)$. Other causes of marrow necrosis include vasoocclusive crisis, direct damage to bone and radiation, and toxins $(9,14,15)$. However, our patient had neither the classic features nor serologic evidence of any of these diseases. The patient had no history of exposure to any other chemical or potential toxins.
There are two explanations for this patient's dramatic illness. First, the condition may have been initiated by an infection that resulted in histiocytic proliferation and macrophage reactivation with excessive cytokine release. Epstein-Barr virus, cytomegalovirus, parvovirus B19, HIV-1 and -2 , and herpes virus are the most common causes of histiocytic proliferation and inhibition of normal hematopoietic cells in adults (5). Epstein-Barr virus infection has a number of different oral manifestations. Affected patients frequently develop cervical lymphadenopathy and may exhibit palatal petechiae, but erosions and ulcers are not typical. Cytomegalovirus usually does not cause oral ulceration $(3,5)$. In our case, the absence of any risk factors for HIV infection made this diagnosis unlikely. Further, all the serology results for viral disease were negative.

A second possible explanation is bone marrow necrosis, and elevated liver enzymes might have been unexplained toxic effects of the St. John's wort the patient was taking for depression. Use of herbal preparations is increasing globally in parallel with alternative medicine. St. John's wort is one of several herbal products used to treat depression (4,8). Previous studies have shown that Hypericum spp. have a number of biological activities. Hypericin, a derivative and the active compound of St. John's wort, is known to have antioxidant and antimicrobial activity $(2,6,13,17)$. Two reports suggest that St. John's wort has anticancer activity, and that it may act by inducing apoptosis and inhibition of cell growth (19). Other research indicates that this herb may also affect drug metabolism by inducing the cytochrome P 450 enzyme (12). St. John's wort has in vitro immunomodulatory effects on lymphocytes, and may alter cytokine release $(10,18)$. The presence of high plasma cytokine levels in our case might reflect such immunological effects that can lead to bone marrow necrosis.

Herbal remedies are used throughout the world, and this report highlights a rare association of herb use and bone marrow necrosis. This case underlines the need for better assessment of the safety of these products.

\section{References}

1. Dasgupta A. Review of abnormal laboratory test results and toxic effects due to use of herbal medicines. Am J Clin Pathol 2003;120(1):127-37.

2. Draves AH, Walker SE. Analysis of the hypericin and pseudohypericin content of commercially available St. John's wort preparations. Can J Clin Pharmacol 2003;10(3):114-8.

3. Ebstain JB, Sharlock CH, Wolber RA. Oral manifestations of cytomegalovirus infection. Oral Surg Oral Med Oral Pathol 1993;75:443-51.

4. Finding RL, McNamara NK, O'Riordan MA et al. An open label pilot study of St. John's wort in juvenile depression. J Am Acad Child Adolesc Psychiatry 2003:42(8):941-9.

5. Gauvin F, Toledano B, Champagne J, Lacroix J. Reactive hemophagocytic syndrome presenting as a component of multiple organ dysfunction syndrome. Crit Care Med 2000 Sep;28(9):3341-5.

6. Gibbone S, Ohlendorf B, Johnson I. The genus Hypericum a valuable resource of anti-staphylococcal leads. Fytoterapia 2002;73(4):300-4

7. Gonzales N, Rios E, Martin-Noya A, Rodriguez JM. Thrombotic thrombocytopenic purpura and bone marrow necrosis as a complication of gastric neoplasm. Haematologica 2002;87(1):ECR01

8. Gupta RK, Moller HJ. St. John's wort. An option for the primary care treatment depressive patients. Eur Arch Psychiatry Clin Neurosci 2003;253(3):113-4.

9. Hamidou M, Rigal-Huguet F, Moreau A et al. Bone marrow necrosis in malignant hemopathies. 7 cases. Rev Med Interne 1993;14:958 
10. Hostanska K, Reichling J, Bommer S et al. Hyperforin a constituent of St John's wort (Hypericum perforatum L) extract induces apoptosis by triggering activation of caspases and with hypericin synergistically exerts cytotoxicity towards human malignant cell lines. Eur J Biopharm 2003;56(1):121-32.

11. Jassens AM, Offner FC, Van Hove WZ. Bone marrow necrosis. Cancer 2000; $88: 1769-80$

12. Markowitz JS, Donovan JL, DeVane CL et al. Effects of St. John's wort drug metabolism by induction of cytochrome P450 3A4 enzyme. JAMA 2003; 290(11):1500-4

13. Pabuccuoglu A, Konyalioglu S, Bas M, Meral GE. The in vitro effects of Hypericum species on human leukocyte myeloperoxidase activity. J Ethnopharmacol 2003 Jul,87(1):89-92.

14. Paydas S, Ergin M, Baslamisli F, et al. Bone marrow necrosis: clinicopathologic analysis of 20 cases and review of the literature. Am J Hematol 2002,70:300-305.

15. Pereira RM, Vellose ER, Menezes Y, et al. Bone marrow findings in systemic lupus erythematosus patients with peripheral cytopenias. Clin Rheumatol 1998, 17:219-22.

16. Sokmen A, Jones BM, Erturk M. Antimicrobial activity of extracts from the cell cultures of some Turkish medicinal plants. Phytother Res 1999 Jun,13(4):355-7.

17. Valentao P, Fernandes E, Carvalho F et al. Antioxidant activity of Hypericum androsaemum infusion: scavenging activity against superoxide radical, hydroxyl radical and hypochlorous acid. Biol Pharm Bull 2002 Oct,25(10):1320-3.
18. Winkler C, Wirleitner B, Schroecksnadel K, Schennach H, Fuchs D. St John's wort (Hypericum perforatum L) counteracts cytokine-induced tryptophan catabolism in vitro. Biol Chem 2004 Dec,385(12):1197-202.

19. Yesilada E, Gurbuz I, Shibata H. Screening of Turkish anti-ulcerogenic folk remedies for anti-Helicobacter pylori activity. J Ethnopharmocol 1999 Sep,66(3):289-93.

Submitted November 2004

Accepted May 2005.

Can Boga, M.D.

Baskent University,

School of Medicine,

Baskent University Hospital,

Department of Hematology,

Dadaloglu Mah. 39. Sokak No: 6, Yuregir

01250 Adana, Turkey.

e-mail:drcanboga@hotmail.com 